Cilt / Volume: 2

Say l / Is sue : 1

Yaz / Sum m er 2021

S e l çu k Ü n i versites i

İslami İlimler Fakültesi Dergisi

\title{
Dataizm: Varlığın Veri Olarak Tasavvuru
}

\section{Burhan Başarslan}

Arş. Gör., Selçuk Üniversitesi, İslami İlimler Fakültesi, Felsefe ve Din Bilimleri Anabilim Dalı

Research Assistant, Selcuk University Faculty of Islamic Sciences, Department of Philosophy and Religious Studies, Konya, Turkey

burhan.basarslan@selcuk.edu.tr (iD https://orcid.org/0000-0001-9459-373X

Yazar

Başarslan, Burhan. “Dataizm: Varlığın Veri Olarak Tasavvuru”. Tevilat 2/1 (2021), 11-25.

do) https://doi.org/10.53352/tevilat.961506

Received / Geliş Tarihi: 2021-07-02

ISSN: 2687-4849 e-ISSN: 2757-654X

Accepted / Kabul Tarihi: 2021-08-26

www.tevilat.com

Bu makale, en az iki hakem tarafindan incelendi ve intihal içermediği teyit edildi.

Bilgi

Çağların değișmesiyle birlikte insan, varlığa dair tasavvurlarını değiștirmiștir. Bu tasavvurların birçok farklı dönemde farklı şekillerde açığa çıktığını görmekteyiz. Varlık tasavvuru insanın varlık ile kurduğu ilișkilerini, eylemlerini, düşüncelerini ve inançlarını şekillendirerek insanın varlık karşısındaki konumunu belirler. $\mathrm{Bu}$ noktada dinlerin, düşünce sistemlerinin ve kültürel geleneklerin farklı varlık tasavvurları ile insanın âlem ile olan ilișkisini düzenleme yönünde öğretilere sahip olduğunu görmekteyiz. Bu öğretilerin insan-varlık ilișkisini düzenleyen ahlaki, siyasi, sosyal, dini, epistemolojik ve kültürel boyutları vardır. İnsanın varlığa dair tasavvuru onun gelecekte elde etmek istediği konumla da doğrudan alakalıdır. İnsan, tarih boyunca aklının ona sunduğu imkanlar nispetinde kendi dışındaki varlığı bilgi ile kayıt altına alarak onu kontrol etmeye ve tüketmeye dönük çabaların içinde kendini bulmuştur. Yine bu çabaların içinde insan günümüze gelindiğinde eski alışkanlıklarını devam ettirmekte ve kendi türünü bir adım ileriye taşımak maksadıyla varlığa ilişkin yeni bir tasavvurun etkisinde varlık ile olan ilişkisini tanzim etmektedir. Veri çağında insanın varlık ile olan ilişkisinde, varlığın veri olarak tasavvur edilmesi birçok yeni teknolojik atılımın önünü açmaktadır. Varlığın veri olarak tasavvuru özellikle ahlaki, epistemolojik ve sosyal anlamda insanın yeni ilişkiler kurmasına yol açmıştır. İnsanın ilişki ağlarını çeşitlendirip geliştirerek ürettiği veriler onun geleceğini şekillendirici rol oynayacaktır.

Anahtar Kelimeler: Felsefe, Varlık, Varlık Tasavvuru, Dataizm, Veri. 


\section{Dataism: The Conception of Being as Data}

With the change of ages, human beings have changed their conceptions of being. We see that these conceptions have emerged in different ways in many different periods. The conception of being determines the position of man in front of being by shaping the relations, actions, thoughts and beliefs of mankind with regard to being. At this point, we see that religions, thought systems and cultural traditions have different conceptions of being and teachings to regulate the relationship of mankind with the world. These teachings have moral, political, social, religious, epistemological and cultural dimensions that regulate the human-being relationship. Man's conception of being is directly related to the position he wants to achieve in the future. Throughout history, human beings have found themselves in efforts to control and consume them by recording the being outside themselves with information, in proportion to the opportunities provided by their minds. Again, within these efforts, on the one hand man maintains his old habits and on the other hand organizes his relationship with being accorging to a new conception of existence in order to carry his own kind one step further. In the age of data, to envision being as data in the relationship of human with being paves the way for many new technological breakthroughs. The envisioning of being as data lead to establish new relationships and take new actions, especially in moral, epistemological and social terms. The data that people produce by diversifying and developing their relationship networks will play a role in shaping their future.

12 Abstract $\quad$ Keywords: Philosophy, Being, Conception of Being, Dataism, Data.

\section{Giriş}

İnsanlık, tarih boyunca geliştirdiği aletlerle kendi işlerini kolaylaştırmayı, daha fazla işi daha kısa sürede yapmayı amaçlamıştır. $\mathrm{Bu}$ sebeple aletlerin kullanım gayeleri ve verimlilikleri insanın alet kullanımında belirleyici olmuştur. Elektriğin hayatımıza girmesiyle insanın işlerini kolay ve hızlı yapma gayesi zirve noktasına ulaşmıştır. Elektrikle birlikte geliştirilen kitle iletişim araçları ise uzak mesafeler arasında bilgi akışının yolunu açmıştır. İnsanlık, telgraf tellerinden e-posta servislerine geçinceye kadar yüz elli yıl beklemiştir. Fakat bu süre daha önceki teknik gelişmeler göz önüne alındığında çok kısadır. İnsanlık, elektriğin sunduğu veri aktarım imSkânı ile son yüzyılda çok hızlı bir teknik ilerleme katetmiştir. Şüphesiz bu ilerlemenin en büyük sebebi iletişim alanında gelişen tekniğin teknolojikleșmesidir. Günümüze kadarki süreçte teknolojik imkanlar ağ kavramı üzerine kurularak iletişim ve paylaşım noktasında ileri noktalara taşınmıştır. Bilgisayar teknolojilerinin insanın daha hızlı ve daha fazla iş yapma yönündeki gayelerini fazlasıyla karşıladığını söyleyebiliriz. Hatta buna ek olarak insanın zihin kapasitesini aşan büyüklükteki bilgiyi düzenleme ișini bilgisayar teknolojileri devralmıştır. Bütün bu kırılmalara ek olarak insan da dönüşmekte ve teknoloji ile arasındaki ilişki basit bir alet kullanımını aşarak ideolojik içerimleri olan düşünsel bir boyut kazanmaktadır. İnsanın artık daha 
hızlı ve daha çok iş yapma yönündeki gayreti yeterli değildir. Bambaşka bir evrende varlığın tamamına farklı bir bakışla yeniden ad ve şekil vererek bütünüyle varlığı yönetmeyi amaçlamaktadır. Bunun içinse sınırsız büyüklükteki veri deposu ve onu düzenleyecek algoritmalar gereklidir.

Hayatımızın her alanında varlığını ve yerini her geçen gün sağlamlaştıran teknolojik cihazlar ve yazılımlar, sağladıkları teknik imkanların yanı sıra insana ve varlığa dair birtakım düşüncelerin açığa çıkmasına da yol açmaktadır. Veri çağında insanın gündelik olarak ortaya koyduğu birtakım yeni edimler söz konusudur; veri toplamak, veri üretmek, veri işlemek, veriye uygun algoritma geliştirmek bunlardan bazılarıdır. Kimi zaman farkında olmadan herkes bu edimler aracılığıyla yapıp ettiklerinden düşündüklerine, söylediklerine kadar her şeyi veriye dönüştürerek saklanabilir hâle getirmektedir. Kuşkusuz her şeyin veriye dönüşmesinin düşünce, ahlak ve varlık görüşü bakımından kaçınılmaz sonuçları da olacaktır. Bu sonuçlardan belki de en önemlisi politik olarak kullanılabilecek bir denetim mekanizmasının veri ağı üzerinden kurulmasıdır. Bunun ne gibi tehlikeli sonuçlara yol açacağını öngörmek güç olsa da imkânsız değildir. Öyleyse insan, veri sisteminin getirdiği politik, sosyal, kültürel birçok alanda hazır olmadığı tehditler ile karşı karşıyadır. Belki de bu tehditlerin en başında varlığa ilişkin tehlikeli sonuçlara yol açabilecek, spekülatif bir düşünüş, bir görme biçimi gelmektedir. Teknolojik gelişim ivmesinin hızla arttığı şu zamanlarda verinin nasıl, ne maksatla, ne şartlarda, ne kadar kullanılacağına ilişkin sınırların belirlenmesinde gecikilen her an veri odaklı "varlık tasavvurunun" güçlenmesine hizmet edecektir.

Veri çağında varlığın yeni bir tasavvurunun ortaya çıktığını söylemiştik. Bu tasavvur, varlığın niceliksel ifadelere indirgenerek kodlanması ve varlıktan devşirilen her bilginin veriye dönüştürülerek varlığın bir veriler toplamından ibaret olduğunun kabul edilmesi şeklinde özetlenebilir. İnsanlık tarihi boyunca varlığın farklı tasavvurlarının olduğunu görüyoruz. Bunlardan bazıları dinler içerisinde yer bulurken bazıları felsefi ekoller içerisinde yer edinmiştir. Örnek olarak İslam tasavvufu içerisinde yer alan İbn Arabî̀nin varlık tasavvuru Hakk, a'yân-ı sâbite, izâfet ve esmâ kavramları ile ilişkilidir. Bir diğer örnek ise Spinoza'nın Tanrı, sonsuz varlık, zorunluluk ve imkân kavramlarıyla ilişkili panteist varlık-Tanrı tasavvuru zikredilebilir. Fransız aydınlanması ile güç kazanarak gelişen maddecilik ise varlığın tamamını maddeye indirgeme eğiliminde olan bir tasavvur sunmaktadır. Bunlar gibi düşünce gelenekleri içerisinde farklı varlık tasavvurlarına rastlamaktayız. Çalışmamızda inceleyeceğimiz varlığın veri olarak tasavvuru geçmişteki birtakım varlık tasavvurları ile benzeșse de özgün bir nitelik arz etmektedir.

\section{Veri Çă̆ı ve Verinin Kullanımı}

Teknolojik gelişmelerin yönlendirdiği yaşadığımız yüzyılın en önemli kaynakları arasında veri/data gelmektedir. 21. yüzyılda gerek reklam ve pazarlama alanlarında gerekse sağlık, sosyal bilimler ve endüstriyel alanlarda verinin önemi izahtan varestedir. Bununla birlikte akademik çevrelerde araştırmaların veri toplama ve işlemeyi amaçlayarak şekillendiğini söyleyebiliriz. Nitekim sosyal bilimler ve fen bilimlerinde varlığa ve insana dair 
çalışmaların büyük bir kısmının örneklemden toplanan veriler tarafından şekillendiğini görmekteyiz. Hatta ikincil analiz yöntemleri ile verilerden hareketle yeni veriler üretildiğini ve "verilerin verisi" üzerinde çalışmaların ortaya çıktığını görmekteyiz. Bir sosyal bilimler araştırmacısı ya da bir tıp doktoru deney alanından veri toplama araçları ile elde ettiği verilerden belirli çıktılara erişmeyi amaçlar. Böylesi bir araştırmada toplanan veri doğrudan doğruya çıktıları şekillendirmektedir. Verinin bütün bilim dallarında kullanımının gittikçe yaygınlaştığını açıkça ifade etmek durumundayız. ${ }^{1}$

Dünyada verinin ve araştırma açısından veri analizinin nüfuz ettiği alanların ne denli çok olduğu düşünüldüğünde verinin önemi daha da anlaşılacaktır. Veri analizi tarihinin insanın bilme serüveni ile paralel gittiğini söyleyebiliriz. Çalıșmaların büyük bir kısmının, tarihten günümüze saha araştırmalarından ve tarihsel materyallerden elde edilen verilerden hareketle oluşturulduğunu görmekteyiz. Verinin hayatımızdaki akademik veya bilgiye kaynaklık eden ampirik yapısının yanı sıra gündelik alanda da önemi oldukça büyüktür. Nitekim kitle iletişim araçlarının gelişimi ve kullanımı ekonomik anlamda az gelișmiş ülkelerin vatandașları göz önüne alındığında dahi azımsanmayacak derecededir. Veri evreniyle olan ilişkiler dünya ölçeğinde çok büyük bir veri deposunu beslemektedir.

Gündelik hayatın vazgeçilmezi olan teknolojik cihazların yaygınlığının ne boyutlara eriștiği geçen aylarda bir mesajlașma uygulamasının gizlilik ilkelerine dönük gittiği bir dizi değişikliğin yol açtığı infial ile gayet açık bir şekilde görülmüş oldu. Verilerin işlenmesi yönündeki sınırların henüz kesinleşmediği bir evrede verinin gizliliği ilkesine aykırı herhangi bir değişikliğin ihtimali dahi bütün dünyanın gündeminde büyük bir yer tutmaktadır. Gizlilik ilkelerindeki değișim ya da hangi verilerin gizli kalabileceğine dair ani bir karar değişikliği ahlaki, hukuki ve siyasi eleștirilerle henüz ilkelere bağlanamamış gibi gözükmektedir. Kişisel verilerin korunması ilkesi, hukukî anlamda bazı verilerin veri sahibinin rızası dışında paylașılmasının önünü kapatmaktadır. Fakat izinsiz veri kullanımının yeterince takip edilememesi dolayısıyla veriyi kaynak olarak tüketen bir sistemde tam anlamıyla gizlilik ilkesinin uygulanması şu an için pek de mümkün gözükmemektedir. Bu doğrultuda insanlığın karşılaşacağı gizlilik ihlalleri ve siber sorunlar ileriki yıllarda çok daha fazla gündemimizde yer tutacaktır. $^{2}$

Verilerin işlendiği ve veri evrenine katkı sunduğu sürece insanlığın daha üst aşamalara yol alacağına inanılmaktadır. ${ }^{3}$ Bununla birlikte gerek endüstriyel anlamda gerekse siyasî anlamda insan ve varlı̆̆ın tamamı bir veriler toplamından ibaret olarak görülmeye başlanmıștır. Siyaset alanında belirli amaçlara matuf söylem oluşturmak için ekonomik, istatistiki ve faaliyet raporu verilerine çokça müracaat edildiği görülmektedir. Herhangi bir siyasi iktidar kendi icraatlarını veriler yoluyla halka duyurmakta ve yine bir hasta kendi

Lohre Steve, Data-ism (USA: HarperCollins Publishers, 2015), 211.

İrfan Atasoy - Okan Ormanli, “Teknoloji Ve Siber Güvenlik: Dijital Toplumun Geleceği”, İstanbul Aydın Üniversitesi Dergisi 11/4 (01 Ekim 2019), 408.

3 Birol Akgül - İlhan Ören, "Yapay Zeka Temelinde İnsan: Dataizm ve Dini Değer Paradoksu”, Medya ve Din Araştırmaları Dergisi 4/1 (29 Haziran 2021), 72. 
bedenine dair veriler ile doktor tarafından değerlendirilmektedir. Psikologlar, danışanlarını istatistiki normlar üzerinden rehabilite etmektedir. Pazarlama ve reklam şirketleri gündelik olarak sürekli kullandığımız teknolojik cihazlardan veri toplayarak tüketim alışkanlıklarımıza göre reklam ve pazarlama politikaları geliştirmektedir. Bütün bunların hepsinde ortak olan noktanın evren ve insana dair farklı bir tasavvura işaret ettiğini söyleyebiliriz.

Sanayileşme ile açığa çıkan hammadde ihtiyacına çağımızda veri de eklenmiştir. Öyle ki kişisel verilerin satılması gibi gündemde sürekli dolaşımda olan haberler bir hammadde pazarlığını anımsatmaktadır. Verinin, çağımızın en kıymetli madeni ve hammaddesi olduğu iddia edilirse, kanaatimizce mübalağa edilmiş olmaz. Kısacası verinin işlenebilir hale getirilmesi ve işlenen verinin kullanılması bu çağın endüstrisi ve akademisinin çokça müracaat edilen yöntemi olarak karşımıza çıkmaktadır. Amerika'daki bazı seçkin üniversitelerde öğrencilerin çok büyük bir kısmı kendi lisans bölümlerine ek olarak bilgisayar teknolojilerine ilişkin dersler almaktadır. ${ }^{4} \mathrm{Bu}$ da gösteriyor ki gerek beşerî bilimlerde ve gerek teknik bilimlerde olsun bilgisayar teknolojileri ve veri analizi araștırma yöntemi olarak kendi yerini her geçen gün sağlamlaştırmaktadır.

\subsection{Veri/Data}

Veri kelimesi, Eski Türkçede mevcut olan "birmek, virmek" fiiline fiilden isim yapan " $i$ " ekinin gelmesiyle türemiştir. ${ }^{5}$ Kelimenin yabancı dillerdeki karşıllı̆g ise Latince "datum" kelimesinin çoğulu olan "data" kelimesidir. ${ }^{6}$ Data ise HintAvrupa dil ailesinde do- kökünden gelmekte olup Türkçe karşılığına uygun olarak "to give" yani "vermek" anlamına gelir. ${ }^{7}$

'Data' kelimesi terim olarak akıl yürütmeyi de kapsayacak şekilde bilgi işlem aygitlarınca işlenebilen ve olguya dayanan bilgi şeklinde tanımlanabilir. ${ }^{8}$ Verilen tanımdan hareketle verinin bir bilgi işlem kaynağı olduğunu söyleyebiliriz. Teknik anlamda; deney alanında olgulardan elde edilen, kayıt altına alınan ve işlenmesi ile çıktılar alınan bilgi şeklinde tanımlanabilir. Datanın en önemli özelliği belki de kayıt altına alınmış olmasıdır. Bu bağlamda kayıt altına alınan bilginin data anlamına geldiğini de söyleyebiliriz.

İnsanın bilgi ile olan serüveni, zihnin verileri işlemesi ile paralellik arz eder. Sanayi çağına kadar veri işleyen makinelerden yoksun olan insanlık, zihnini yegâne veri işleme aygıtı olarak kullanmak durumundaydı. Buna ek olarak insan zihni, varlığı tanımak, bilmek, kayıt altına almak, varsayımlar yapmak gibi amaçlarla matematik dilini oluşturdu. Matematiğin yükselişi ve teknolojik ilerlemelerle birlikte fonksiyonel algoritmik yazılım dilleri meydana geldi. $\mathrm{Bu}$ diller insana hesap ve ișlem gücünü daha ileriye tașıma, depolama alanını genişletme gibi yeni imkanlar sundu. Bu dillerin temel mantığı, çıktı almak

\footnotetext{
Steve, Data-ism, 211.

"Nişanyan Sözlük”, Nişanyan Sözlük (2021 2002).

Şevki Ișikli, "Büyük Veri, Epistemoloji ve Etik Tartışmalar”, AJIT-e: Bilişim Teknolojileri Online Dergisi 5/17 (01 Eylül 2014), 92.

7 “etymonline”, www.etymonline.com (2021 2001).

8 Işikli, "Büyük Veri, Epistemoloji ve Etik Tartışmalar", 92. Ayrıca bkz. https://www.merriamwebster.com/dictionary/data\#synonyms erişim: 19.01.2021
} 
üzerine kuruludur. En basit şekliyle 'işlem' denen matematiksel olay dahi bir çıtı alma diyalektiğini ifade eder. İşlemin ilerleyen düzeyinde ise algoritmik ve fonksiyonel matematik, günümüz teknolojisinin ve yapay zekânın işlem mantığını oluşturur. Veri, sayılara dönüşerek belirli amaçlara dönük algoritmalar ile ayıklanır ve çıtıllar elde edilir. Veri bilimciler matematik ve bilgi işleme güçlerini veriyi anlamlı kılmak için kullanırlar. ${ }^{9} \mathrm{Bu}$ noktada insan zekâsının da belirli algoritmalar aracılığıyla veriden hareketle sonuç elde ettiğini ve buna klasik bilimlerden bu yana mantık adı verildiğini söyleyebiliriz. Yapay zekâ, makine öğrenmesi gibi veri işleme olayları da algoritmalara dayanan sonuç elde etme çalışmalarıdır. Tabii ki bunun ötesinde algoritmalar, veri setleri, büyük veri ve karar mekanizmalarıyla donatılmaya çalışılan yapay zekâ araştırmaları, ilerleyen yıllarda çok daha büyük anlamlar ifade edecek düzeye gelebilir. Yapay zekâ ve insan zihni arasındaki farkın zekâ ve bilinç ayrımında yattığı söylenebilir. ${ }^{10}$ Bilinç insanın tecrübe alanının insandaki bilgi ve farkındalık durumunu ifade ederken ${ }^{11}$, zekâ tecrübe alanından toplanan verinin işlem yoluyla bilgiye dönüştürülmesi ve sonuçlara erişilmesini ifade eder. ${ }^{12}$ Dolayısıyla doğal ya da yapay olsun zekâ, insan ve makinede ortak bir nitelik olarak kabul edilebilirken, bilinç insana özgü durmaktadır.

Bu noktada verinin temelde iki farklı türünün olduğunu söylemekte fayda gözükmektedir. İlki, insanın yüz binlerce yıldır duyu ve akıl yoluyla elde ettiği, verilerdir. Bunlar genellikle insan hayatında zihnin çözümlediği verilerdir. Diğer veri türü ise insanın zihin kapasitesini așacak derecede hacimli ve insan zihniyle düzenlenmesi adeta imkânsız olan verilerdir. Bu veriler daha çok "dijital veri" kategorisindedir ve bu verinin işlenmesi için insanın zihin kapasitesini aşan işlem gücüne sahip bilgisayarlara ve yazılımlara ihtiyaç vardır. Şimdilik bu verinin çıktılarından hareketle aksiyon alan yine insandır. Ancak ilerleyen yıllarda bu verinin düzenlenmesi, işlenmesi ve analiz edilmesi süreçlerine ek olarak insanın karar mekanizmasını etkileyen faktörlerden hareketle karar mekanizmasını destekleyen yönlendirici yazılımların varlığını daha da derinden hissedeceğimizi öngörmek mümkün gözükmektedir. Karar mekanizmasını destekleyen araçların güvenlik ve sınırlılık bağlamında yol açacağı sorunlar gelecekte daha çok gündemimizde yer alacaktır. ${ }^{13}$

Verinin endüstriyel kullanımı noktasında üretim aşamasından pazarlama aşamasına kadar ortak bir matematiksel değer sisteminin işlediğini söyleyebiliriz. Endüstride bir şeyin tasarımında o şeyin nicelik ve nitelikleri, matematiksel karşılıkları kullanılarak veri işleme yoluyla üretilir. Ayrıca üretilen şeyin kullanım alışkanlıklarına uygunluğu yine kullanıcı deneyimi verilerinden hareketle șekillenir.14 İnsanların kullanım alıșkanlıklarına göre tasarımların açığa çıkması da yine verilerin pazarlama ve reklam yönünden kullanımına

\footnotetext{
Steve, Data-ism, 15.

Y. N. Harari, Homo Deus, çev. Poyzan Nur Taneli (İstanbul: Kolektif Kitap, 2016), 414.

"Consciousness - APA Dictionary of Psychology" (Erişim 17 Ağustos 2021).

"Intelligence - APA Dictionary of Psychology" (Erişim 17 Ağustos 2021).

Gloria Phillips-Wren - Lakhmi C. Jain, “Artificial Intelligence for Decision Making” 20/10 (2012), 11.

14 Armağan Kuru, “Teknolojik Ürünlerde Kullanıcı Deneyimi Üzerine Bütünsel Bir Model”, Mühendislik Bilimleri ve Tasarım Dergisi 3/3 (25 Aralık 2015), 570.
} 
örnektir. Buna ek olarak insan psikolojisine dayanan verilerin de yine tasarım, pazarlama ve reklamcılık teknikleri açısından önem arz ettiğini biliyoruz. İnsanın etkilenen konumunda bulunduğu reklam, pazarlama ve tüketim endüstrilerinde psikolojik veriler etkin ve etkili pazarlama için kullanılmaktadır. Hatta tüketim toplumunda yaratılan ihtiyaçların insan psikolojisine dayanan verilerle şekillendiğini de görmekteyiz.

Buna ek olarak verilerin siyasi kurum ve kişiler tarafından da kullanıldığını görmekteyiz. Sürekli medyadan ilan edilen ekonomik veriler, anket sonuçları ve diğer istatistikler kamuoyu için gittikçe siyasi görüşleri belirleyen bir ölçüt olmaya başlamıştır. Veri, tıp alanında kişisel verilerin paylaşılması noktasında birtakım etik sorunların gündeme sıkça gelmesine sebep olsa da ${ }^{15}$ hastalıkların norm ve standartlarının belirlenmesinde tedavi ölçütlerinin tayin edilmesinde sıklıkla kullanılmaktadır. Biyo-istatistik, temelde insana ait tıbbi ölçümlerden elde edilen verilerin kullanımına dayanmaktadır. Tıp alanında bir başka örnek ise yoğun bakım ünitelerinde kullanılan cihazlardır. Bu cihazlar hastaların tıbbi verilerini her an toplayarak analiz eden, olumsuz durumlarda sinyal veren algoritmalarla çalışır. ${ }^{16}$ Veri kullanımının insanın hayat şartlarını kolaylaştırdığını zikrettiğimiz örnekler üzerinden açıkça görmekteyiz. Diğer yandan sayıların dünyasından kendi dünyamıza ilişkin birtakım öngörülere sahip olup gelecekte gerçekleşmesi muhtemel olaylara karşı harekete geçebiliriz. Geleceğe dönük tahminler ve determinasyon ile oluşturulmuş ihtimaller alanı bizi öngörülebilir felaketler karşısında önlem almaya sevk edebilir.

Verinin sosyal araștırmalarda da kullanımından hareketle din bilimleri alanında yapılan araştırmalarda da verinin rolü azımsanmayacak kadar çoktur. Fakat araştırmaların din bilimi alanında büyük veriden beslenen kaynaklara atıfla yapıldığını söyleyemeyiz. Daha çok nitel ve nicel veri toplama araçlarından gelen veriler bu alandaki araştırmaları şekillendirmektedir. Büyük veriden beslenen internet arama motoru verileri, çerez veriler gibi dijital izlere henüz bu araștırmalar kapsamında müracaat edilmemektedir. $\mathrm{Bu}$ tarz verilerin kullanımına örnek olarak Ramazan aylarında arama motorlarına girilen verilerden hareketle en çok tartışılan veya merak edilen konular hakkında çıkarımda bulunulabilir ve bu yönde bilgilendirici etkinliklere yetkili kurumlar ya da özel teşebbüsler yönlendirilebilir. Bölgesel olarak dini konulardaki tartışmaların ne yönde şekillendiği takip edilerek yerel teşkilatlarca bilgilendirici etkinlikler düzenlenebilir. Bununla birlikte bilgi çağında karşılaşılan en büyük sorunun doğru bilgi sorunu olduğu göz önüne alınırsa doğru dini bilgiye erişilmesi yönünde dijital izlerden hareketle düzenlemelerde bulunulabilir. Büyük verinin sağladığı imkanlardan biri verilerin birbirine bağlı olarak değer ifade etmesidir. Bu bağların ne şekilde ve ne sıklıkla oluştuğunun gözlemlenmesi veriyi işlevsel kılmaktadır. Dijital dünyada her şeyin birbiri ile bağlı olduğu düşünüldüğünde dini araştırmalar açısından büyük veriden hareketle elde edilecek çıktılar siyasi, ekonomik, sosyal vb. birçok alanda tekrar tekrar kullanılabilecektir.

15 Abdullah Uçar - İlhan İlkiliç, "Büyük Verinin Sağlık Hizmetlerinde Kullanımında Epistemolojik ve Etik Sorunlar”, Sağlık Bilimlerinde İleri Araştırmalar Dergisi 2/2 (06 Eylül 2019), 88.

16 Steve, Data-ism, 2. 


\subsection{Büyük Veri/Big Data}

Büyük Veri kavramı 1997 yılında ilk kez teknik anlamda kullanılmıştır. ${ }^{17}$ 1997 yllından günümüze dek büyük veri kavramının çokça konuşulan ve tartışılan bir kavram olduğunu ifade etmek gerekir. Büyük verinin özellikleri noktasında farklı yaklaşımlar ortaya atılmıştır. Bunlardan biri, "Büyük veriyi büyük yapan, tüm veri setinin mümkün olan en büyük bölümünün kullanılmasıdır"18 şeklindedir. Bir diğeri ise büyük verinin düzensiz, ilişki kurulmamış veriler yığını olması dolayısıyla işlemesi ve analiz edilmesi daha karmaşık algoritmalarla çalışan üstün makineneler ile mümkün olduğu şeklindedir. ${ }^{19}$

Büyük veri düzenlenmediği, ayıklanmadığı takdirde işlevsellik kazanamayacaktır. Genel anlamda verinin kendisinin işlenmediği sürece bilgi değeri açı̆̆a çıkarılamaz. Büyük veri ile ifade edilenin daha çok hacim, çeşit ve hız ile alakalı olduğu ifade edilmiștir. ${ }^{20}$

Büyük veri birçok alanda kullanılabilir bir niteliğe sahiptir. Fakat ifade edildiği gibi her alanın kendi amaçlarına uygun algoritmalar geliștirerek bu veriyi kullanılabilir hale getirmesi gerekmektedir. Örnek olarak borsa piyasasında büyük verinin, uygun pazarlama ve öngörü tahmini maksadıyla oluşturulan algoritmalar aracılığıyla kullanıldığı verilebilir. ${ }^{21}$

Ülkemizde büyük verinin akademik çalışmalarda kullanımının 2011 yllından itibaren artan bir ivmeyle çoğaldığını söyleyebiliriz. ${ }^{22}$ Büyük verinin önümüzdeki yıllarda düzenleyici ve analiz edici algoritmaların geliştirilmesiyle farklı alanlarda daha aktif kullanılacağını öngörmek yerinde olacaktır. Zira takip edilmesi gittikçe güçleşen insan davranışları, alışkanlıkları ve sosyal alandaki olayların çeşitlenmesi büyük veriye müracaat etmeyi zorunlu kılmaktadır. Araştırmacıların nicel ve nitel veri toplama araçlarıyla nüfuz edemeyeceği noktalara büyük verinin düzenlenmesi aracılı̆̆ıyla erişim imkânı sağlanabilmektedir. ${ }^{23}$ Buna ek olarak büyük veri, geliştirilen algoritmalar ve yapay zekâ ile birlikte geleceğe dönük karar verme mekanizması haline gelebilir. ${ }^{24}$

17 Uçar - İlkiliç, "Büyük Verinin Sağlık Hizmetlerinde Kullanımında Epistemolojik ve Etik Sorunlar”, 81.

18 Ișikli, "Büyük Veri, Epistemoloji ve Etik Tartıșmalar", 92.

19 Işikli, "Büyük Veri, Epistemoloji ve Etik Tartışmalar", 92-93.

20 Suat Atan, "Veri, Büyük Veri Ve İşletmecilik", Balıkesir Üniversitesi Sosyal Bilimler Enstitüsü Dergisi 19/35 (01 Haziran 2016), 147.

21 Danah Boyd vd., "Büyük Veri Üzerine Eleștirel Sorular: Kültürel, Teknolojik ve Bilimsel Bir Olgu Hakkında Eleștirel Sorgulamalar", Folklor/Edebiyat 21/83 (01 Aralık 2015), 201.

22 Serkan Bayrakçı, Sosyal Bilimlerdeki Akademik Çalışmalarda Büyük Veri Kullanımı (İstanbul: Marmara Üniversitesi Sosyal Bilimler Enstitüsü Gazetecilik Anabilim Dalı Bilișim Bilim Dalı, Yüksek Lisans, 2015), 113.

23 Boyd vd., "Büyük Veri Üzerine Eleştirel Sorular", 203.

24 Steve, Data-ism, 3. 


\section{Varlığın Niceliksel Tasavvurları: Pisagorculuk'tan Dataizme}

Dataizm ilk olarak 2013 yılında The New York Times'da yayımlanan bir yazıda terim olarak kullanılmış ${ }^{25}$, Steve Lohr'un Data-ism ${ }^{26}$ ve Harari'nin Homo Deus adlı eserlerinde ise daha kapsamlı ele alınmıștır. Dataizm çağımızın bilgi işlem teknolojileri bakımından ilerlemesi sebebiyle şu anki gündemimize yeni bir kavram olarak eklenmiştir. Harari'nin bu kavramın üzerinde bu denli duruyor olması birkaç sebebe mebnidir. Ona göre çağımızda bilginin ve bilgi teknolojilerinin konumu hayatiyet arz eden bir ehemmiyete sahiptir. Harari, bu önemin nereden kaynaklandığına ilişkin tespitlerde de bulunur. Harari'ye göre Dataizm bilgisayar algoritmalarının biyokimyasal sırları açığa çıkarabileceğine inanmaktadır. ${ }^{27} \mathrm{Bu}$ durum bilgisayar teknolojilerinin biyolojiye yakınlaşması ile canlılık denen şeyin veri ve algoritma aracılığıyla sırlarının çözülebileceği inancıdır. Bazı çalışmalar, karmaşık fiziki sistemlerin işleyişlerinin kaydedilerek ileriki zamanlarda yönetilebilir hale geleceğini ön görmektedir. ${ }^{28}$ Dataizm bütün varlığın bir veriler toplamından ibaret olduğunu ve her varlığın veri olarak değerlendiği bir varlık görüşüne sahiptir. ${ }^{29}$

Varlığın nicelik olarak tasavvuru tarihte birçok defa karşımıza çıkmaktadır. Antik Yunan'da Pisagorculuk, akabinde Yeni Pisagorculuk ve semavi dinlerde asketik ve ezoterik bazı akımlar yer yer varlığı açıklarken sayıları kullanmışlardır. Dikkat çekici bir nokta olarak Antik Yunan'da M.Ö. 6. yüzyılda açığa çıkan Pisagorculuk, semavi dinler içinde gelişen ve sayı olarak varlığı açıklamaya çalışan akımlarla benzerlik arz eder. Antik Yunan'da bir din olarak görülen Pisagorculuk, bahsi geçen semavi dinlerdeki yapılar gibi arınma ritüellerine ve dışa kapalı bir yapıya sahipti. Dataizmi de içine alacak şekilde bütün bu yapıların genel özelliği varlık ile sayılar arasında ontolojik bir ilişki kurarak, varlığı sayılar ile açıklamaktır. Kimi zaman semavi dinlerde varlığın dildeki karşılıkları olan isimler üzerinden belirli hesaplarla harf-sayı sistemi geliştirilerek bu ilişki kurulmuştur. Bunun en bilindik örneği ebced hesabıdır. Ebced, harflere verilen belirli sayı değerleri ile 'şey'e ait olan adın sayısal hesabı arasında ilişki kurmak anlamına gelmektedir. Harflere sayı değeri verilerek ebced hesabı yapılması Grek, Latin, İbrani ve Arap alfabelerinde tarih boyunca kullanılmıștır. ${ }^{30}$ Ebced hesabının bir ismin sayısal değerine erișmek ve o ismin ait olduğu varlık ile sayı-isim-şey arasında bir ilişki kurmak için kullanıldığını söyleyebiliriz. Sayı-isim-şey arasındaki ilişkinin şeyin adının ve sayısal değerinin bizzat o şey ile temsil bağıntısı kurularak oluşturulduğu açıktır. Varlıktaki çeşitliliğin ve farklılığın niceliksel olarak açıklanması ve bir düzen ile beraber aynılık arayışı bu düşüncenin temelini teşkil eder.

\footnotetext{
25 David Brooks, “The Philosophy of Data”, The New York Times (04 Şubat 2013).

26 Steven Parton, "The Rise of Dataism: A Threat to Freedom or a Scientific Revolution?" (30 Eylül 2018).

Harari, Homo Deus, 384.

Steve, Data-ism, 124

Harari, Homo Deus, 383.

30 M. İsmet Uzun, “Ebced”, TDV İslâm Ansiklopedisi (Erişim 23 Mart 2021).
} 
Pisagorculuk'ta varlığın düzeni sayılarla mümkündür. ${ }^{31}$ Sayı, varlığın ortak noktası, düzeni, bütünleştiği şey ve arkesidir.32 Pisagorcular sayıları geometri ile beraber kullanarak şeylere bazı sayıları tayin etmişlerdir. Onlar için noktalardan oluşan üçgenler, dörtgenler çok önemli ve hatta üzerine yemin ettikleri çok güçlü ifadelerdi. ${ }^{33}$ Bununla birlikte Pisagorculuk, dini öğreti boyutunu niceliksel varlık açıklaması ile birleștirerek ruhun ölümsüzlüğünü de vaz' etmiştir. Pisagorculuk'ta ve ebced hesabında sayıların varlığı açıklamak için kullanılması dataizmin varlığı veri olarak tasavvur etmesi ile benzeşmektedir. Veri de nihayetinde sayıya dönüştürülmüş olguya dayanan bilgidir. Varlığın geçmişten günümüze sayı ile açıklanmasında bahsi geçen tasavvurların bir başka ortak yönü ise ölümsüzlük idealidir. Dataizmde biyoloji ve bilgisayar teknolojilerinin bu denli yakınlaşması ölümsüzlük gibi bir hedefin koyulması sonucunu doğurmuştur. Bunun muhtemel bir sonucu olarak transhümanizm de belki de Sümerlerden beri aranan ölümsüzlüğün peşine düşmüştür. ${ }^{34}$

Neticede Pisagorculuk, ebced ve dataizm, ifade ettiğimiz gibi bir noktada ortaktır. En özet ifadesiyle bu nokta, varlığın nicelik olarak ifade edilmesi ve öz niteliklerinin sayısal hale dönüştürülmesidir. Bu yapıların tamamı ile dini bir hüviyet taşıdığını görmekteyiz. Bütün bu izahlardan hareketle dataizmin bir din olarak ihtiva ettiği varlık, ahlak ve bilgi hakkındaki görüşlerini zikretmek yerinde olacaktır.

\subsection{Dataizmde Varlık ve İnsan}

Bahsi geçen dataizmin varlık tasavvurunun insana dair ahlak, bilgi ve değer alanlarında da birtakım fikirler doğurduğunu görmekteyiz. Dataizmde insanın varlık içindeki konumunun merkezi öneme sahip olduğunu söyleyebiliriz. Zira insan bütün verinin kontrolünü sağlayacak olan algoritmaları ve verinin bizzat kendisini üreten varlıktır. Veri evreninde insan hem üreten hem tüketen hem de tüketilen konumundadır. Evren bütünüyle bir veri akışından oluşmakta ve insan bu veri akışına katılmaktadır. Böylelikle insan bireysel veri akışına katıldıkça sürekli veri üreten bir çip vazifesini ifa eder hale gelmektedir. ${ }^{35}$

Harari'nin ifadesiyle dataizm, büyük verinin düzenlenmesiyle açığa çıkan kozmosta insanı mutlu kılan ve hatta insana hayatın anlamını veren bir dindir. ${ }^{36}$ İnsan veri akışına katıldıkça kendi yapıp ettiklerini, düşüncelerini diğer insanlarla paylaşmaya alışarak her türlü deneyimini veri paylaşım ağı üzerinden veri evrenine iletmek durumundadır. İnsan kendi deneyimlerini öteki ile paylaşamayacaksa hiç deneyimlememeyi belki de tercih eder duruma gelecektir. 37 Veri çağında insanın deneyimlerinin paylaşım üzerinden değerli ve anlamlı

31 Guthrie, İlkçağ Felsefesi Tarihi, 45.

32 Ahmet Arslan, İlkçağ Felsefe Tarihi 1-Sokrates Öncesi Yunan Felsefesi (İstanbul: İstanbul Bilgi Üniversitesi Yayınları, 2006), 151.

33 W.K.C. Guthrie, A History of Greek Philosophy (USA: Cambridge University Press, 1991), Volume $1 / 225$.

34 İshak Doğan, “Transhümanizm: 'Allah'ın Yarattığını Değiştirme’ veya İnsana Karşı Şeytan 2.0”, Marife 21/1 (2021), 14-16.

35 Harari, Homo Deus, 402.

36 Harari, Homo Deus, 403.

37 Harari, Homo Deus, 403. 
olduğunu görmekteyiz. Bunun veri akışını sürekli hale getirdiğini ve büyük veriyi besleyerek çeşitli maksatlara uygun tasarlanmış algoritmalara veri sunduğunu açıkça ifade etmek gerekir. İnsanın değeri deneyimlerini veriye dönüștürmekle ölçülür hale gelmekte ve işlevsellik yönünden bu şekilde değerlendirilmektedir. ${ }^{38}$ Algoritmaların veriler ile gelişmesi insanın veri akışına katılmasının önemini daha da artırarak hem insan için hem veri sistemi için mutual bir ilişki kurmaktadır. Algoritmalar insanın isteklerini ve eylemlerini yönlendirecek düzeye evrildiğinde ise tam bir uyum ile çalışan yüksek ihtimallere sahip sonuçlar doğacaktır. Algoritmalar insanın zihin kapasitesini aşan bir veri yükünü işlediğinden her ne kadar insan üretimi olsalar da kendi sorunlarına ve aksaklıklara çözüm üreterek öğrenmeye başlayacaktır. ${ }^{39}$

Dataizmin yükselişi ve insana dair bakışı, veri çıktılarının ifade ettiği değerlerdir. Canlıların biyokimyasal algoritmaları bilgisayar algoritmaları tarafından çözümlenmeye çalışılmaktadır. İnsan da yapısı bakımından biyokimyasal algoritmalardan oluşur. $\mathrm{Bu}$ algoritmalar da sunulan verileri işleyerek insan düşüncesini ya da eylemlerini çıktı olarak verir. Dolayısıyla bilgisayar algoritmaları insanın biyokimyasal algoritmaları ile ne denli benzeşirse, insanın bilgisayar algoritmalarından aldığı çıktılar ile bilgisayar algoritmalarının insan için sunduğu çıktılar birbirine yaklaşacaktır. Böylece insanın düşünceleri ve eylemleri bilgisayar algoritmaları ile elde edilen yüksek ihtimallerle örtüşmeye başlayacaktır. Bu durumda insan da veri evreninin dışında kalarak sadece veri kaynağı işlevi görecektir.40

Bu durumda insan da tıpkı diğer varlıklar gibi algoritmaların özerkliğini ilan etmesinden sonra sadece veri kaynağı görevini ifa edebilir. Elbette bu durum da Harari'nin tahmini sonuç olarak ileriye dönük öngörüleri arasındadır. Her ne kadar şu an için mümkün gözükmese de insanın veri akışına olan katılımının her geçen gün gittikçe arttığını düşündügümüzde algoritmaların daha da gelişerek yavaş yavaş insanı düșünce ve eylemlere sevk edeceğini söyleyebiliriz. Hatta günümüzde propaganda aracı olarak kullanılan sosyal mecralar insanı bir simülasyonun içine alarak kendi örülmüş veri evreninde eyleme veya düşünceye sevk edebilmektedir. İnsanın, veri evreninde belirleyici rolden belirlenen role, etken oluştan edilgenliğe geçmesi yine de gelecek yıllarda ihtimaller dahilindedir diyebiliriz.

Nitekim insanın ve bütünüyle varlığın veriden ibaret olduğuna ilişkin görüşü destekler nitelikte birçok örneğe hayatımızda rastlamaktayız. Çarpıcı bir örnek olarak Steve Lohr ileri teknolojik cihazlarla donatılmış bir yoğun bakım odasındaki doktorun, cihazlar ve cihazların sağladığı veriler arasında hastayı görmesinin gittikçe zorlaştığını, doktorun gözünde hastanın bir protoplazma kütlesi ve bunla ilișkili veriler toplamından ibaret hâle geldiğini söyler. ${ }^{41}$

Varlığın veri olarak tasavvur edildiği bu evrende determinizm değil ihtimaller hüküm sürmektedir. Determinizm geçmişin ve şimdinin olgusallığını açıklarken, veri evreni geleceğin nasıl olacağını güçlü tahminlerle

\footnotetext{
Harari, Homo Deus, 404-405.

Harari, Homo Deus, 410.

Harari, Homo Deus, 407.

Steve, Data-ism, 35.
} 
şekillendirmeye imkân tanımaktadır. İhtimaller dünyasında belki de en büyük gaye, geleceğe dair verilere dayalı en iyi tahminde bulunmaktır. ${ }^{42}$ Çünkü geleceğin iyi bir tahmini, bize bugünün düzenlenmesinde çok fazla şey söyleyecektir.

\subsection{Dataist Veri Ahlakı}

Dataizmin veri ahlakı ile alakalı genel kabulleri yine Harari'nin eserinde görmekteyiz. Fakat dataizmi ezoterik bir yapı olarak görmemek gerekir. Günümüzde bilgi işlem sektöründe, bilgisayar teknolojilerinde çalışan birçok mühendis, tasarımcl, analist belki de dataizmin umdelerini benimsemiş bir şekilde çalıșıyor. Dataizm bütünüyle bilgi endüstrisine hâkim olan bir düşünceler toplamına ek olarak inançlar alanını da içermektedir.

Dataizmin gerek ahlak noktasında gerekse inanç noktasında söyledikleri bilgi teknolojileri ve insan yaşantısının gittikçe bütünleştiği noktada anlam kazanır. Dataizme göre insan kendi elleriyle hazırladığı veri evrenini kendi geleceğini iyileştirmek için kullanmalıdır. İnsan veri sisteminin daha iyi ve daha etkili çalışabilmesi için daha fazla veri üretmelidir ve bu veriye özgürce erişebilmelidir. ${ }^{43}$ Dataizm insanlığın gelecekte daha iyi bir noktaya gelebilmesi için verinin özgürleşmesi gerektiğini savunur. $\mathrm{Bu}$, dataist veri ahlakının temelidir. Kim ne maksatla olursa olsun veriye erișebilmelidir. Verinin özgürleșmesini savunmak, dataizmin bir ahlak düșüncesine de sahip olduğunu gösterir. Verinin özgürce kullanımı ve karşılaşılan sorunlar, yine geliștirici ve onarıcı yazılımsal çözümleri beraberinde getirecektir.

İnsan ve varlığın tamamı veri deposunu sürekli olarak besleyerek yeni algoritmaların önünü açacaktır. Veri, bilgi demektir. Bilginin özgür bir şekilde dolaşıma sokulması demek bilginin kolay erişilebilir ve katlanarak büyüyen bir niteliğe sahip olması demektir. Katlanarak büyüyen veri insanlığın gelişimine hizmet edeceğinden saklanması veya erişiminin kısıtlanması veri ahlakı açısından kabul edilebilir değildir.

Veri ahlakının bu özgürleștirici yaklașımı insanın kötü gayelere dönük çabalarına karşı savunmasız bir pozisyonda olduğuna işaret etmektedir. Dataistler, bu pozisyondan ancak verinin düzenlenmesi ve sorunların giderilmesi ile kurtulabileceğimiz inancına sahiptir. Klasik ahlak ilkelerinden sıyrılarak verinin işlerlik kazanması ve büyümesi adına bir ahlak ilkesi vaz' edilmiştir. $\mathrm{Bu}$ ilke, verinin özgür kullanımı ve özgürce çoğaltılmasıdır. Mahremiyetin ihlal edilemezliği gibi klasik ahlaki ilkeler daha üstün amaçlar uğruna feda edilerek veri çağının ahlakını oluşturur. İnsanlar veri ağına katıldıkça değerlendikleri için değer ve ahlak veriye katılmak ve onu beslemek ile gerçekleşir.

Dataizmin veri ahlakı onun bir din olarak belirmeye başladığının en belirgin göstergesidir. ${ }^{44}$ Bunun yanında dataizm bir inanç alanına da sahiptir. İnsanlığın

Steve, Data-ism, 63.

Harari, Homo Deus, 388-389.

Harari, Homo Deus, 397. 
aydınlanma devrinde tıpkı "bilgi güçtür" dediği gibi bugün dataizm "veri güçtür" demektedir.

\subsection{Dataizmde Bilgi ve Bilimlerin Birliği}

Dataist varlık görüşünden bahsettiğimiz bölümden hareketle, varlığın tamamının niceliksel bir ifadede ortaklaşması birçok farklı bilimsel alanın da aynı dili kullanmasına imkân tanımaktadır. ${ }^{45}$ Bütün bilimlerin ortak dili kullanıyor oluşunu belki de bilgisayar teknolojileri ile biyolojik sistemleri açıklama çabasına borçluyuz. Biyolojik algoritmaların bilişim algoritmaları tarafından taklit edilmesi ile canlılık teknolojikleșmeye başlamıştır. Bunun sonucu olarak canlılığı taklit eden teknolojiler üretilmeye başlanmıştır. Bütün bunların ötesinde biyoloji ile teknoloji arasındaki derin yarık ise varlığını sürdürmektedir. Bu yarık, bilinç kavramıdır. Zekâ ve bilinç kavramının birbirinden ayrıldığını ve hatta biyoloji ve teknolojiyi de birbirinden ayırdığını söyleyebiliriz. Fakat bilinçten çok zekâ ile ön plana çıkan bilgi işlem teknolojileri elde ettiği başarılar sayesinde ön plana çıkmıștır. Zekâ, bilgiyi işleme kapasitesinin arttırılması ile paralellik arz eden bir gelişime sahiptir. Yapay zekâ insanın sahip olduğu bilinç durumlarına sahip olmamakla beraber zekâ kapasitesi olarak insanın önüne geçme tehlikesini taşımaktadır. ${ }^{46}$ İnsanın tecrübelerinden elde ettiği verilerin onun zekâsından daha iyi çalıșan ve daha farklı ilişkiler kurabilen bir zekâya emanet edildiğinde daha farklı ve iyileştirici sonuçlar alınacağına inanan dataistler, algoritma ve makine öğrenmesini insanın zekâsına tercih ederek algoritmalara daha çok güvenmektedir. ${ }^{47}$

Verinin özgürleşmesi ve yaygınlaşması için veri sağlayıcı sayısının arttırılması gerekmektedir. Bu gerekliliğe ek olarak veri sağlayıcıları arasında ilişkiler kurulmalı ve veri işlenmelidir.48 Verinin işlenir hale gelmesi için veri akışının büyümesi yani iletişimin artması gerekmektedir. Bu da her an arama motoruna girdiğimiz her karakter ile internette yaptığımız her tık ile beslenen bir veri ağının nasıl büyüdügünü bize gösterir: "iletişim".

\section{Sonuç}

Veri çağında insanın yeni bir varlık düşüncesinin içinde kendini bulduğunu söyleyebiliriz. Bu niceliksel olarak varlığın tasavvur edilmesi, işleme alınması, düşünülmesi anlamına gelmektedir. Fakat varlığın asli halini göz ardı eden bu düşünce etik, ontolojik ve metafizik birçok soruna gebedir. Bu çalışmada değinilmemiş olan bu problemlerin belki de düşünsel kökenine işaret edilmektedir. Varlığa ilişkin niceliksel bir tasavvur olan dataizmin, varlığı veri sağlaması ya da verileşmesi bakımından değerlemesi varlığın ontolojik değerini örtmektedir. Bir şeyin ne ise o olduğunu göremeyecek derecede bir düşünsel körlüğe sebep olabilecek bu varlık görüşü, verinin egemen olduğu çağımızda belki de insanın şimdiden en çok ihtiyaç duyduğu şeyi ondan koparıp almaktadır.

\footnotetext{
Harari, Homo Deus, 385.

Harari, Homo Deus, 414.

Harari, Homo Deus, 385.

Harari, Homo Deus, 394-395.
} 
Varlık ile karşılaşmanın bu denli güçleștiği bu çağda insan veri katmanlarının arkasında yer alan varlığı göremeyecek derecede körleşmektedir.

Varlığın veri olarak tasavvuru her ne kadar eski kültürlerdeki birtakım varlık tasavvurlarıyla belirli noktalarda benzeşse de kendine özgü bir nitelik arz etmektedir. Biyoloji ve teknolojinin bu denli yakınlaştı̆̆ı ve algoritmaların biyolojik organizmaların işleyişleri konusunda çözümleyici rol üstlendiği bir çağda biyolojik organizmaların teknolojikleșmesi gibi sonuçlar gün yüzüne çıkmaktadır. Bütün bunlarla birlikte varlığın veri olarak tasavvur edilmesi, veriden gelen bilginin siyasi ve sosyal alanda güç olarak kullanılmasına yol açmaktadır. İlerleyen süreçte verinin sunduğu büyük imkânlar değerlendirildikçe üstlendiği politik roller çeşitlenecektir. İnsanın inanç dünyasından duygu durumlarına dek ruhi varlığı da nicelik olarak varlık görüşü karşısında önemini yitirmeye başlayacaktır.

Unutulmaması gerekir ki varlığın nicelik olarak tasavvuru, aslolan varlığın ıskalanması ve insanın deneyim çeşitliliğinin daraltılmasına sebep olmaktadır. İnsanın gelişen teknolojinin imkanlarından faydalanmak maksadıyla edindiği teknolojiler terkedilmesi imkânsız alıșkanlıklar kazandırarak insanın varlık içindeki konumunu tekrar düşünmeye bizleri mecbur bırakmaktadır.

\section{Finansman / Funding:}

This research received no external funding. / Bu araștırma herhangi bir diş fon almamiştır. 


\section{Kaynakça}

Akgül, Birol - Ören, İlhan. "Yapay Zeka Temelinde İnsan: Dataizm ve Dini Değer Paradoksu". Medya ve Din Araștırmaları Dergisi 4/1 (29 Haziran 2021), 65-79. https://doi.org/10.47951/mediad.947374

Arslan, Ahmet. İlkçağ Felsefe Tarihi 1-Sokrates Öncesi Yunan Felsefesi. İstanbul: İstanbul Bilgi Üniversitesi Yayınları, 2006.

Atan, Suat. "Veri, Büyük Veri Ve İșletmecilik”. Balıkesir Üniversitesi Sosyal Bilimler Enstitüsü $\begin{array}{llll}\text { Dergisi } & 19 / 35 & \text { (01 Haziran }\end{array}$ https://doi.org/10.31795/baunsobed.645312

Atasoy, İrfan - Ormanli, Okan. "Teknoloji Ve Siber Güvenlik: Dijital Toplumun Geleceği". İstanbul Aydın Üniversitesi Dergisi 11/4 (01 Ekim 2019), 399-409.

Bayrakçı, Serkan. Sosyal Bilimlerdeki Akademik Çalıșmalarda Büyük Veri Kullanımı. İstanbul: Marmara Üniversitesi Sosyal Bilimler Enstitüsü Gazetecilik Anabilim Dalı Bilişim Bilim Dalı, Yüksek Lisans, 2015.

Boyd, Danah vd. "Büyük Veri Üzerine Eleştirel Sorular: Kültürel, Teknolojik ve Bilimsel Bir Olgu Hakkında Eleștirel Sorgulamalar". Folklor/Edebiyat 21/83 (01 Aralık 2015), 199-215.

Brooks, David. "The Philosophy of Data". The New York Times (04 Şubat 2013). https://www.nytimes.com/2013/02/05/opinion/brooks-the-philosophy-of-data.html

Doğan, İshak. “Transhümanizm: 'Allah'ın Yarattı̆̆ını Değiştirme' veya İnsana Karşı Şeytan 2.0”. Marife 21/1 (2021), 11-36.

Guthrie, W.K.C. A History of Greek Philosophy. USA: Cambridge University Press, 1991.

Guthrie, W.K.C. İlkçağ Felsefesi Tarihi. çev. Ahmet Cevizci. Ankara: Gündoğan Yayınları, 1999.

Harari, Y. N. Homo Deus. çev. Poyzan Nur Taneli. İstanbul: Kolektif Kitap, 2016.

Ișikli, Şevki. "Büyük Veri, Epistemoloji ve Etik Tartışmalar". AJIT-e: Bilișim Teknolojileri Online Dergisi 5/17 (01 Eylül 2014), 89-122. https://doi.org/10.5824/1309-.. 1581.2014.4.006.x

Kuru, Armağan. "Teknolojik Ürünlerde Kullanıcı Deneyimi Üzerine Bütünsel Bir Model”. Mühendislik Bilimleri ve Tasarım Dergisi 3/3 (25 Aralık 2015), 567-574.

Parton, Steven. "The Rise of Dataism: A Threat to Freedom or a Scientific Revolution?" 30 Eylül 2018. Erişim 17 Ocak 2021. https://singularityhub.com/2018/09/30/the-rise-ofdataism-a-threat-to-freedom-or-a-scientific-revolution/

Phillips-Wren, Gloria - C. Jain, Lakhmi. "Artificial Intelligence for Decision Making" 20/10 (2012), 1-13.

Steve, Lohre. Data-ism. USA: HarperCollins Publishers, 2015.

Uçar, Abdullah - İlkiliç, İlhan. "Büyük Verinin Sağlık Hizmetlerinde Kullanımında Epistemolojik ve Etik Sorunlar”. Sağlık Bilimlerinde İleri Araştırmalar Dergisi 2/2 (06 Eylül 2019), 8092. https://doi.org/10.26650/JARHS2019-616389

Uzun, M. İsmet. “Ebced”. TDV İslâm Ansiklopedisi. Erişim 23 Mart 2021. https://islamansiklopedisi.org.tr/ebced

"Consciousness - APA Dictionary of Psychology". Erişim 17 Ağustos 2021. https://dictionary.apa.org/consciousness

www.etymonline.com. "etymonline". 2021 2001. Erișim 19 Ocak 2021. https://www.etymonline.com/word/*do-

"Intelligence - APA Dictionary of Psychology". Erişim 17 Ağustos 2021. https://dictionary.apa.org/intelligence

Nişanyan Sözlük. "Nişanyan Sözlük". 2021 2002. Erișim 19 Ocak 2021. https://www.nisanyansozluk.com/?k=ver-\&lnk=1

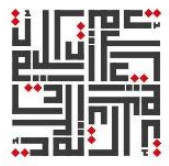

